\title{
Anthropology, Politics, and Place in Sri Lanka: South Asian Reflections from an Island Adrift
}

Jonathan Spencer

\section{(2) OpenEdition}

Electronic version

URL: https://journals.openedition.org/samaj/3812

DOI: $10.4000 /$ samaj.3812

ISSN: $1960-6060$

Publisher

Association pour la recherche sur l'Asie du Sud (ARAS)

\section{Electronic reference}

Jonathan Spencer, "Anthropology, Politics, and Place in Sri Lanka: South Asian Reflections from an Island Adrift", South Asia Multidisciplinary Academic Journal [Online], 10 | 2014, Online since 25

December 2014, connection on 21 September 2021. URL: http://journals.openedition.org/samaj/3812 ; DOI: https://doi.org/10.4000/samaj.3812

This text was automatically generated on 21 September 2021.

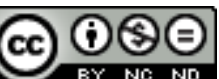

This work is licensed under a Creative Commons Attribution-NonCommercial-NoDerivatives 4.0 International License. 


\title{
Anthropology, Politics, and Place in Sri Lanka: South Asian Reflections from an Island Adrift
}

\author{
Jonathan Spencer
}

For Tambi

Something is missing in many maps of Sri Lanka. ${ }^{1}$ If it isn't missing it is simply reduced, faded, played down. That something is India:

Official maps
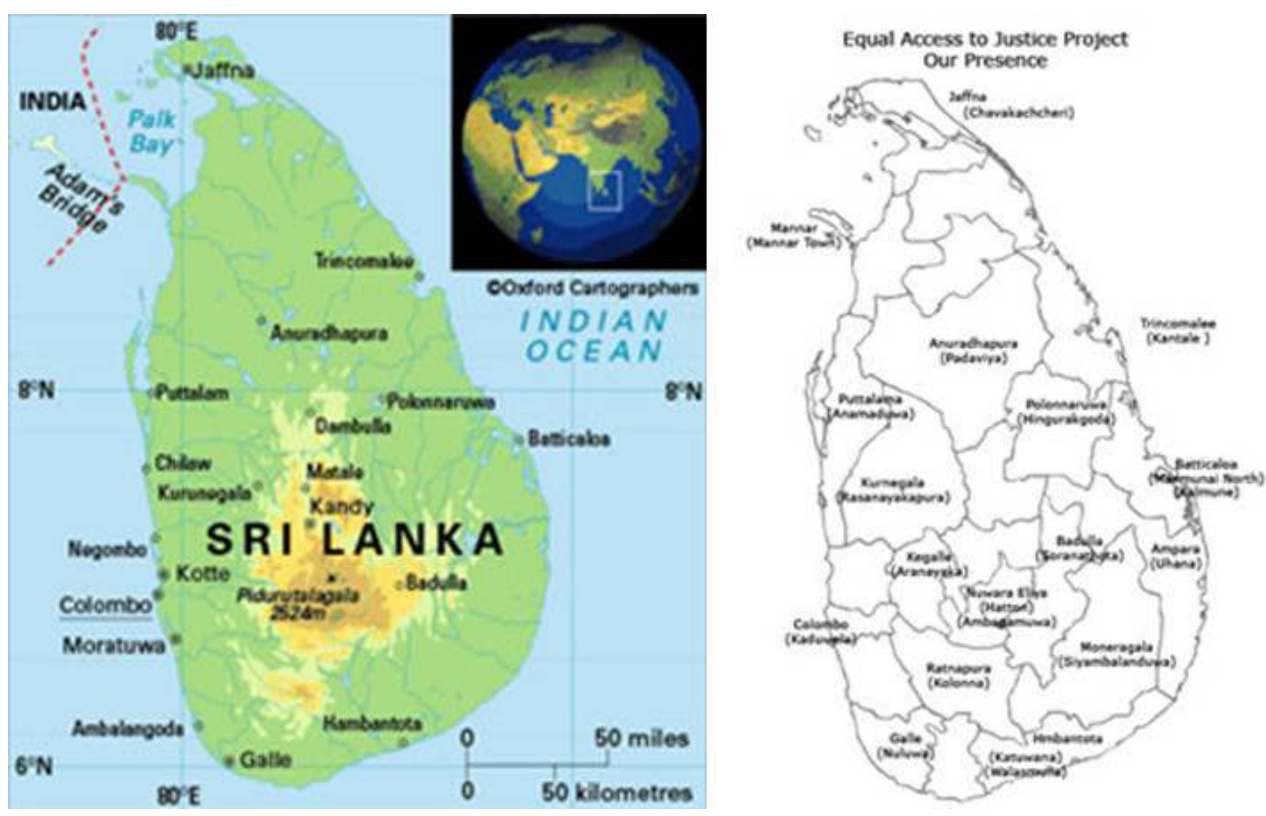

LEFT: COMMONWEALTH SECRETARIAT. RIgHT: SRI LANKA gOVERNMENT WEBSITE. 
2 How did Sri Lanka get to drift away from the land mass to which it seems so almostattached? Indeed why is Sri Lanka a separate place, a different country, a different anthropology? I doubt many Sri Lankans, let alone researchers working on the island, would be able to give an answer. When the Dutch colonies around the coast of the island passed to the British in 1796 they were briefly under the control of the Madras Presidency of the East India Company. This morphed into a system of dual control, shared with the crown, before Ceylon formerly became a crown colony of its own in 1802. Thereafter it was controlled from the Colonial Office in London, not by the Company, and it shared its $19^{\text {th }}$ century rulers with Fiji and New Zealand, rather than Madras and Bombay. Why? The reasons for this outcome are deeply embedded in local rivalries between different British agencies of the time. It could easily have been otherwise. But as Sujit Sivasundaram has recently pointed out, the consequences were profound, in both governmental and imaginative terms. Attempts to dredge a deeper channel between the island and the mainland provide a nicely concrete metaphor for the ideological separation established in early colonial rule (Sivasundaram 2013:14). We have one source of these outlines of an island adrift, apparently disconnected from its neighbours, at once South Asian and notSouth Asian.

\section{‘Local Society'?}

3 For the last 15 years I have spent a large part of each summer with my family on an island in the Outer Hebrides. The island is way out in the far, far west with nothing but brimming ocean between it and Canada. To get there requires a six or seven hour ferry journey from the mainland. Once there, you feel you are on the very edge of the continent.

4 Our closest neighbour is a man I shall call Roderick. Roderick is a fluent Gaelic speaker, born and brought up on the island. But, as I have slowly got to know him over the years, I find his conversation to be full of surprises. Once, when I mentioned my own trips to Sri Lanka he merely said, 'Now I do remember going to Trincomalee more than once', his accent adding a syllable or two to the name of the Sri Lankan port, thus bending the anglicized place name closer to its local rendition, tirikunamali. In his youth Roderick had worked for years in the merchant navy, had circled the globe more than once, and could tell Conradian tales of his experience on pilgrim ships taking flocks of hajjis from Malaya and Indonesia to Mecca. Nor was he especially unusual in his travels. Another neighbour, two houses up the road, is now retired, but used to work on the oil rigs in the North Sea; after the North Sea, he found work in other oilfields in different places, ending up working for years in the Gulf of Mexico before coming home to the island. Roderick and his neighbour, and others like them, are both deeply located in the place of their birth, but their sense of emplacement is set against a life in which economic necessity sent them across the world and something else brought them back. My opening point is simple. To adapt what Geertz once said of villages-people live on islands, but they don't necessarily stay on islands.

5 We may think of islands as sealed, enclosed, worlds in themselves, bubbles of various sorts (cultural, political, whatever). But this is simply wrong. Islands are rarely any of these things. They are places of harbour, and places of transit, points of arrival and points of departure. Their popular representation as closed worlds of their own is not a self- 
evident reflection of the experience of living on islands: it is something that requires quite a bit of cultural and political work, and the result of this work is rarely stable or seamless. As Charles Hallisey once put it, in a situation like this, every invocation of the 'local' inevitably invokes a coeval invocation of the 'translocal'. A historian of medieval Buddhism, Hallisey has been an active participant in some of the most interesting discussions about place in recent South Asian scholarship, and I will return to those discussions later in this paper (Pollock 2003).

Another conversation, this time in 2006 in Ampara District in Sri Lanka, brought this home to me. With the sociologist Tudor Silva, I was visiting one of Sri Lanka's smallest and most disadvantaged universities, Southeastern University, which is located on the edges of a fishing village called Oluvil right on the island's East coast. Tudor and I were there to advise the University on curriculum development in sociology and anthropology. The current undergraduate programme was entirely taught by two enthusiastic but hardpressed junior lecturers. One thing they told us they wanted was more material for the students which addressed 'local society'. The cry is common among social scientists teaching all over Sri Lanka, for whom until very, very recently, almost nothing of academic worth about Sri Lanka was available in the local languages used for university teaching. But the situation was especially vexed in Oluvil. The students at Southeastern University are over $90 \%$ Tamil-speaking Muslims-a minority within a minority-and their University is itself the product of the long civil war which has ravaged this part of the country. It was formed in the mid-1990s when Muslim students and staff at the University further up the coast withdrew from that campus, citing the constant threat of attack from the Liberation Tigers of Tamil Eelam.

7 So what would constitute 'local society' for these people? Not the classic ethnographies of kinship and land tenure that dominated the literature when I started out as a $\mathrm{PhD}$ student in the early 1980s (Leach 1961, Obeyesekere 1967). Nor the literature on Buddhism, politics and change which followed (Gombrich \& Obeyesekere 1988, Obeyesekere 1981, Seneviratne 1977, 1998), or ritual and sorcery (Kapferer 1983, 1997). We could, it's true, have built the entire syllabus on the excellent work of Dennis McGilvray (2008), most of which was researched within a bus ride of the Oluvil campus, supplemented by a chapter or so from Under the Bo Tree (Yalman 1967), but that was about it (I dread to think how they would have reacted to Margaret Trawick's eccentric take on the war (Trawick 2007): based on fieldwork an hour's drive away, it might as well have been written about the planet Mars for all its 'local' resonance in Oluvil). We might have looked to Indian textbooks and treated 'local society' as an outpost of India proper (the Outer Hebrides of South Asia, perhaps) but this idea met with little enthusiasm. The lecturers themselves had suggested 'Islamic society' as a way to conceive their kind of place, but we were unsure this would deliver the kind of teaching material they seemed to need. Finally, I tried an idea which did seem to work: 'Local society', for a place like Oluvil, really meant the Indian Ocean rim - from Kerala upwards along the west coast of the subcontinent to Gujarat, the ports of the Arabian Gulf, the old trading routes down the coast of East Africa, plus the predominantly Muslim coasts of Malaysia and Indonesia. This resonated in all registers. Everyone knew someone who had travelled north to the Gulf for employment. Everyone knew the stories of Arab traders arriving in Sri Lanka, marrying local women and settling down to found the Muslim communities now living along the coast (not least because these stories became the official rationale for treating 'Moors' as 'racially' distinct from Tamils in late $19^{\text {th }}$ century colonial sociology). And everyone knew 
the other reason for Oluvil's limited fame-the imagined super-port that a local politician had promoted for the village, which was intended to reawaken the great days of the old trade routes. The politician had died in murky circumstances some years before. All there was to show of his dream harbour at this point was a fine Islamo-vernacular lighthouse, a mile or so down the beach from the campus.

Oluvil lighthouse

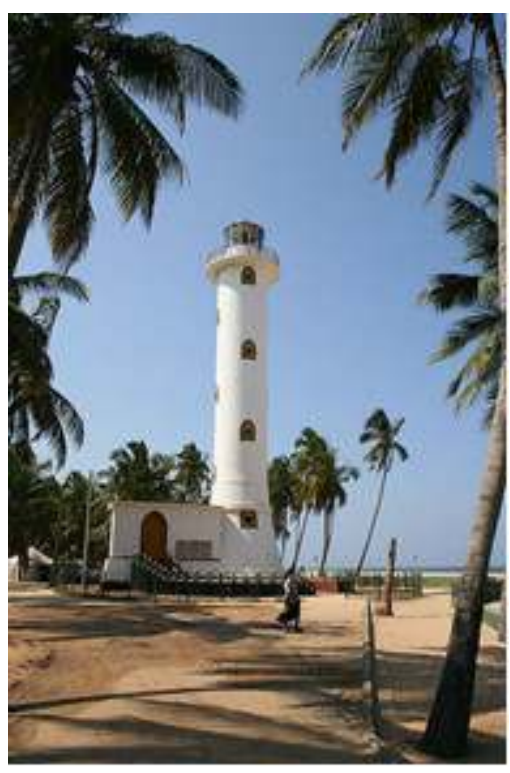

PHOTOgRAPH BY THE AUTHOR.

Looking out from the lighthouse, the local is not a place but a process. Islands are good sites to watch this process at work. And islands like the island of Sri Lanka are perhaps best thought of not as closed entities but more as sieves or colanders, through which persons, ideas and theories pass, leaving odd bits and pieces behind on their passage. All this passing is not without its problems and predicaments, and from these problems some of us make anthropology.

\section{Connected anthropologies?}

9 My reflections on South Asia as seen from its southern extremity were not, as may already be obvious, originally formulated for the context in which they now appear. They were first drafted in response to an invitation to think about the somewhat more specific topic of South Asia as a context for anthropological theory. Thinking about Sri Lanka in terms of its proximity to, and distance from, the bigger thing that is South Asia, can, I think, illuminate our understanding of the island (not least its current venomous politics). It can also shed light on why Sri Lanka has been such a fruitful site for the making of anthropologists. I will return to the question of politics, and specifically the anxieties of post-war place-making in Sri Lanka, in my concluding comments. First, though, I want to step back from anthropology and instead steal an idea or two from the historians of the region. I should stress that I am not pretending that what follows has much if any substance as a contribution to the history of anything (Sri Lanka, 
anthropology, whatever): rather I am using a perspective derived from these historians because, as they say, it is good to think with. Anachronism is the least of my problems.

In a contribution to a symposium on early modern history in South and Southeast Asia a decade ago, Sanjay Subrahmanyam (1997) launched the idea of what he called 'connected histories'. Ostensibly commenting on a six-country comparison by the historian of Southeast Asia Victor Lieberman, Subrahmanyam chose to propose a radically different way of approaching the history of early modern Asia and Europe. One component of Subrahmanyam's argument is an implicit critique of what has elsewhere been called 'methodological nationalism' (Wimmer \& Glick-Schiller 2002), this time as manifest in the historiography of the early modern world. ${ }^{2}$ In the case in hand, he means the treatment of entities called 'Burma', 'Siam', 'Vietnam', as well as 'France', 'Russia' and 'Japan' as selfcontained and self-evident units for analysis and comparison. In place of this kind of comparativist perspective, Subrahmanyam argues for a kind of analysis which takes the issue of connections across distance seriously as a point of departure. The flows that link different parts of the early modern world in his analysis are as often ideological as material (both matter, of course) and they extend far beyond the familiar contours of the 'expansion' of western Europe, a theme which he suggests may have been of only marginal importance in many parts of Asia in the period in question.

11 Subrahmanyam takes as one example the Arakan court (in present-day Burma/ Myanmar), 'wherein the court chronicles were written in Pali, but where Persian was used, and Bengali the major language of literary expression' (Subrahmanyam 1997: 757). Arakan, he reminds us, was tied into a network of Buddhist polities, including those in Sri Lanka, held together by flows of monks and more material representatives of the Buddha, in the form of relics. This Buddhist ecumene persisted well into the $19^{\text {th }}$ century in ways both predictable (the importation of Siamese and Burmese monks to restart the ordination tradition around the turn of the $19^{\text {th }}$ century) and unpredictable (King Mongkut of Siam providing some of the money for Buddhist monks to run their first Sinhala-language printing presses in the mid-19 ${ }^{\text {th }}$ century (Malalgoda 1976:219, see Blackburn 2010).

Another example might be the movement of people from South India to Sri Lanka, and then from Sri Lanka onwards and outwards into the world. The movement of Tamil people since the early 1980s, into a growing diaspora in Western Europe, North America and Australia can be seen as a continuation of earlier patterns of movement: educated Tamils from the Jaffna peninsula supplied South India and Malaya with schoolteachers and clerks; South India in turn supplied the colonial plantations of Ceylon with coolies to harvest the coffee, rubber and tea (Spencer 2003, Thiranagama 2014). Before that, the Palk Straits were for centuries a crossing point for all manner of people and goods, with groups of incomers being absorbed in local hierarchies of caste, family and religion. But, as Sunil Amrith (2013) has eloquently demonstrated, if we attend to the movements of migrants across the Bay of Bengal, we find ourselves thinking in terms of a rather different region, a region which includes Singapore and Penang, as well as Colombo and Kolkata, and therefore a region which undermines the coherence of received ideas about Southeast as well as South Asia.

13 One obvious way to respond to this argument is to abandon any talk of 'an' anthropology of Sri Lanka (or, to stick to Subrahmanyam's original point, an anthropology of 'South Asia' or 'Southeast Asia'), and try to develop a kind of fluid anthropology, which can treat the very idea of place as inherently problematic, and which is less embarrassed by all this 
evidence of movement and connection (see Ludden 2003). One can see the stirrings of this in the early fiction of Amitav Ghosh $(1992,1993)$, in the renewed interest in migration across the sub-continent (Gardner \& Osella 2003), in the study of the politics and performances of border-crossing (Samaddar 1999), or in recent work on cross-Indian Ocean networks of people and places (Gilsenan 2003, Ho 2006). Two contributions from the history of religion demonstrate the possibilities inherent in such an approach to our understanding of Sri Lanka. Anne Blackburn's Locations of Buddhism (2010) systematically shifts attention from the well-rehearsed story of colonial interactions between Western and local Buddhists, to focus instead on relations with Buddhists elsewhere in Asia, especially in Thailand. Ronit Ricci's Islam Translated (2011) provides a virtuoso analysis of the movements of a single narrative, the Book of One Thousand Questions, from $10^{\text {th }}$ century Arabic, through Tamil, Javanese and Malay translations, conjuring up another new spatial configuration-the Arabic cosmopolis of South and Southeast Asia. Towards the end of her tale, she introduces an 1897 Malay manuscript, written in jawi script in Colombo, which connects the story to the lineage of Abdul Qadir Al-Jilani, the Sufi saint whose network of shrines links Sri Lanka to Tamil Nadu, Singapore and Penang (Ricci 2011: 209-12). From this kind of geographically expansive material we might begin to construct the kind of account of 'local society' my young colleagues in Oluvil were looking for.

But I want to explore a rather different implication of Subrahmanyam's argument. His article is aimed at a number of well-chosen targets: at Eurocentric accounts of the modern; at overly materialist readings of movement and connection in the early modern; and at those who think the world has only very recently discovered travel, connection, and the intellectual consequences of connection. One of these consequences is a set of more or less 'anthropological' predicaments which can be discerned in the transcultural exchanges that pepper the history of early modern travel: issues of translation abound, of course in all registers, but so too do exchanges concerning fundamental assumptions about human life and sociality, of what it is to be a person. Subrahmanyam describes an extraordinary conversation between the Mughal ruler Akbar and a visiting Jesuit on their different ideas about the imminence of the Last Judgement, and then traces the circulation of millenary ideas and images across the supposed religious and cultural boundaries of the region. In Subrahmanyam's argument 'difference', and the desire to render it intelligible or fix it in classificatory schemas, was never solely an issue for Europeans venturing into Asia.

15 Again, to seek a Sri Lankan illustration for this point, we can point to the most famous proto-ethnographer of the island, the English sailor Robert Knox, who published his account of life in the kingdom of Kandy in the late $17^{\text {th }}$ century. Knox's account is based upon 20 years spent in Ceylon as a (rather generously treated) captive of the king of Kandy. While contemporary anthropologists happily read Knox as a Malinowskian fieldworker avant la lettre (e.g. Kapferer 1990), they rarely reflect on the peculiar circumstances of his captivity. Knox was one of a significant number of Europeans who were detained for many years on the orders of the King of Kandy, not, it would seem, for any obviously instrumental reasons-no ransoms were demanded, no treaties negotiated -but rather for reasons of curiosity. The editor of my early $20^{\text {th }}$ century edition notes:

The causes of their detention were:

(i) a quaint whim of King Rajah Singho to make a sort of menagerie of European

captives;

(ii) the jealousy of the Dutch at the possibility of English intervention; 
(iii) the disinclination of the captives themselves to make a determined effort to escape. (Knox 1911 [1681]: xiii-xiv)

In short, the pioneer ethnologist was himself a specimen in the King's personal ethnological museum. From the start, ethnography cut both ways.

Vedda chieftain and portrait of Robert Knox
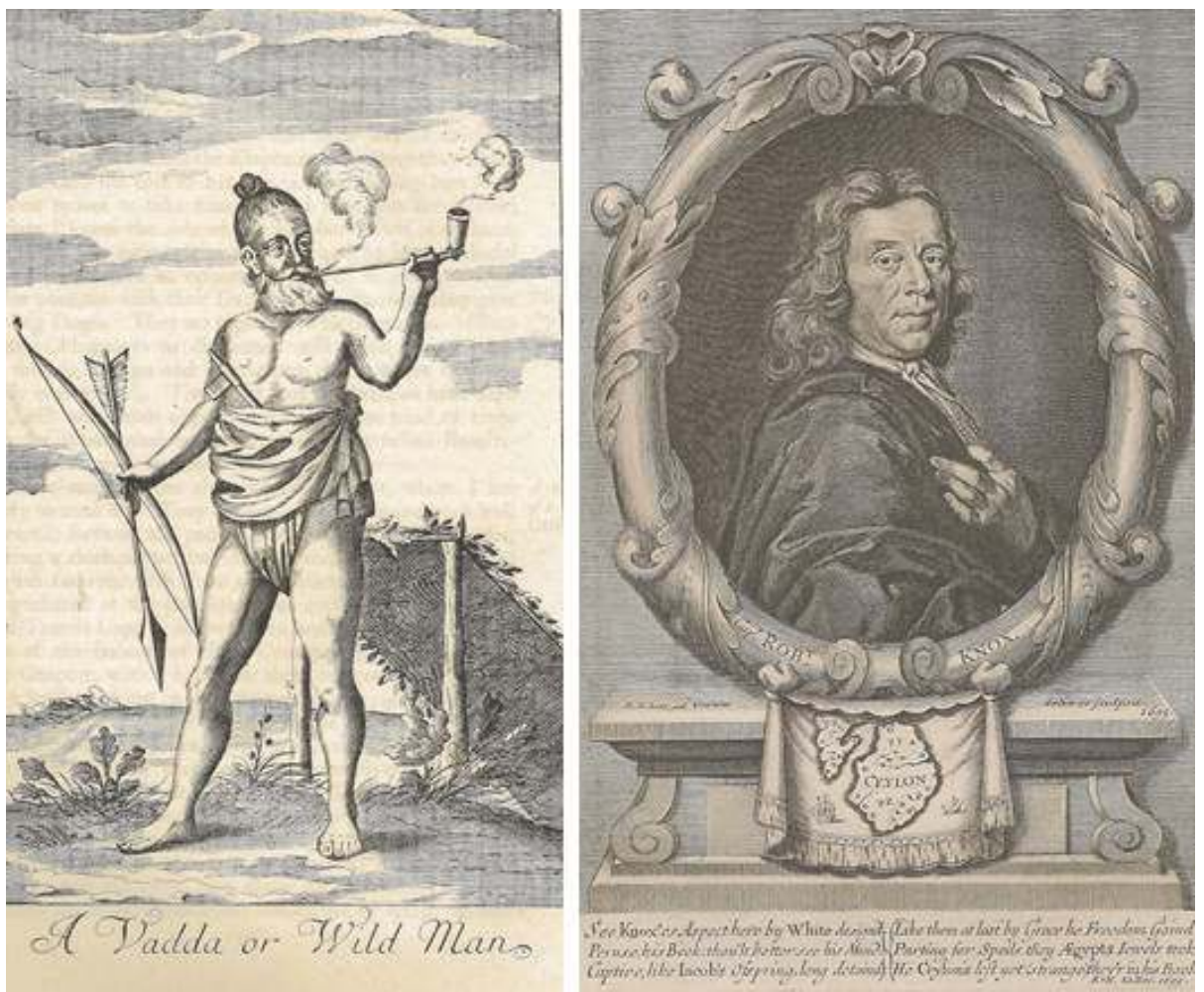

AN HISTORICAL RELATION OF THE ISLAND CEYLON IN THE EAST INDIES (1681)

\section{Anthropology as place-making}

There is one other lesson I want to draw from this rather dubious and breathless tour of early modern Asia. That concerns the local and the supra-local and the making of place. The inspiration from this comes from a different source-Sheldon Pollock's comparative model of vernacularization and cosmopolitanism in early modern Eurasia. Comparing the histories of Latin and Sanskrit, Pollock points out on the one hand a parallel process of expansion followed by vernacularization, in which '[n]ew, local ways of making culturewith their wholly historical and factitious local identities-and, concomitantly, new ways of ordering society and polity came into being, replacing the older translocalism' (Pollock 2000: 592). Across the sub-continent new literary cultures emerged, using Tamil, Marathi, Kannada in place of Pali or Sanskrit.

Much of Pollock's argument concerns the different modalities of the cosmopolitan and the vernacular that emerged in Europe and, somewhat differently, in South Asia. What interests me is his vision of the local as something that emerges from an earlier translocal culture. The local, in this instance, is not given, it is consciously produced. The translocal is not something in our future, it is very much there in the deep past. "What some are inclined to characterize as vernacular primordiality,' he argues, 'is shown to be a 
chimera; vernacularity has always and everywhere been produced' (Pollock 2000: 617). In South Asian versions of the early modern vernacular, the key element is not people so much as 'Place'. Vernacularization is attached to what Pollock calls an 'aesthetic of Place', itself expressed above all in the new literary 'languages of Place' (desha-bhasha).

Two points stand out. I would like to believe that Sri Lanka's geographic position makes it especially vexed by the dilemmas of vernacularization. The sheer duration and impact of colonial rule-which lasted unbroken for over 400 years in parts of the seaboard-is probably the other troubling factor, something which produces and reproduces place as a problem to be overcome. The problem of place-making is never resolved there but has to be undertaken anew in each generation. Certainly, it is noteworthy that in the chronology of Pollock's epochal account, Tamil and Sinhala appear early as vehicles of vernacular literature in their own right and stay the course until the present (Hallisey 2003). ${ }^{3}$ The second is that the classic stories of indigeneity in Sri Lanka work within a structure of feeling dominated by movement, travel, and the supplanting of what is already there by what has come from outside: the Buddha comes to the island and leaves the places blessed by his presence; the founder of the Sinhala kings, Vijaya, comes and marries a wild local woman. And having arrived from elsewhere, the new force settles and becomes the very essence of the place of arrival.

Whatever the antecedents, anthropology in Sri Lanka has been, for much of the time, an exercise in making and marking the place. 'Anthropology' as cosmopolitan idiom is harnessed to exercises in locating, valorizing and fixing the essence of place. To take an example I have used more than once before (Spencer 1990, 2007): the most prominent literary figure of the years after Independence, the Sinhala novelist Martin Wickramasinghe, drew on Malinowski and Benedict in his writings on Sinhala culture, stressing the permeability of cultural boundaries and the value of cultural borrowing, even as he sought to locate the 'real' heart of Sinhala culture in traditional village life. Out of the same 1950s literary milieu emerged two of Sri Lanka's many brilliant anthropologists, Gananath Obeyesekere and Gehan Wijeyewardene. Obeyesekere has recounted the first part of his own life of to-ing and fro-ing between the cosmopolitan and the local:

As an undergraduate at Peradeniya I, like many others of my generation, wondered about my social and personal identity. I had left my own village in early childhood and then lived in Colombo and Kandy. Though I did go back to my village during school vacations, I was never really a part of its social existence. Moreover, my village was a considerably acculturated one, characteristic of parts of the Western and Southern provinces. Inspired by a romantic quest for the really real, I used to wander during university weekends and vacations into remote villages in the North Central Province to collect folk songs and myths. I felt increasingly drawn toward understanding village culture, thereby hoping (futilely, I soon learned) to abolish my own alienation. (Obeyesekere 1984: xv)

Or Daniel on his own cosmopolitan circumstances:

I am a native Tamil speaker, born in the Sinhalese-speaking south of Sri Lanka to a South Indian Tamil father who changed his name from something divine to something daring in order to marry my mother, a Sri Lankan Anglican whose mother tongue was English. My father's English was poor, his Sinhalese ineffective; my mother's Tamil was excruciating, her Sinhalese reserved for the servants. For me, at least, anthropologizing began early. (Daniel 1984: 57)

Daniel's Fluid Signs starts with the story of a rich visitor from Malaysia drawn back to his ancestral village in Tamil Nadu in order to make arrangements for his son to come and 
spend time there, to 'live on its soil' (Daniel 1984: 62). The book, with its fascination with ur, the Tamil concept of village-as-origin-and-essence, is at once about-and an example of-the making and marking of place.

For others, place-making has happened at one remove. Some, like Chandra Jayawardena, found themselves as anthropologists by recapitulating the routes of the coolie migrants of the 19th century, in his case to Guyana and Fiji. Others like Wijeyewardene and Tambiah, traced the contours of the old Buddhist ecumene which linked Sri Lanka to Southeast Asia. Tambiah has described his anthropological journey to Thailand (after experiencing an early round of Sinhala-Tamil violence) in these terms:

And intuitively reading the signs, I wished to get away from the island, for I experienced a mounting alienation and a sense of being homeless in one's own home. And then a remarkable opportunity came my way, which enabled me to positively sympathize with and creatively study the phenomena in another country that I could not do in my own. I went to Thailand.

He continues: 'In a complex way, I sense that [World Conqueror and World Renouncer] was an attempt at an intellectual and emotional confrontation with and resolution of my own personal situation with regard to Sri Lanka, and the conflicts and urges it gave rise to' (Tambiah 1986: 137-8).

Place-making is never a dispassionate exercise. What links this generation of brilliant anthropologists is the strong normative dimension in their work. Obeyesekere set out to look for the 'really real', Tambiah lamented the 'betrayal' of Buddhism in its modern nationalist orientation. Seneviratne's Work of Kings (1999) is a remarkable reading of modern Buddhist polemics, made up in equal parts of interpretation and admonition. Much of this normative concern focuses on Buddhism, and especially its link to the vicious politics of friend and enemy. In seeking out their version of the real, anthropologists have played a central role in challenging and destabilizing other, more popular, claims to the heart of things Sinhala and things Tamil. As a result, they have become frequent figures for public vilification in Sri Lanka itself. Tambiah's Buddhism Betrayed (1992) was banned by the government in the 1990s as a result of a campaign by chauvinist critics. Obeyesekere is often attacked in the local press. But their crime is not the empty deconstruction of sacred symbols of nation and people. Their crime is the use of the anthropological lens to argue for other, better ways to configure the heart of this place.

\section{The view from the lighthouse}

In 2009, as the long civil war came to an end, someone in the Sri Lankan tourist authority had the bright idea of marketing the island as part of a 'Ramayana Trail', carefully packaged to attract Indian tourists eager to see the home of Ravana. The plan was immediately contested by a group of voluble intellectuals associated, not unironically, with the Royal Asiatic Society of Sri Lanka. A symposium was organized in 2010, with presenter after presenter disowning the plan. As the opening speaker explained:

The Archaeology Department has strict rules and laws against the destruction of archaeological sites; however there are no laws for the opposite-creation of bogus sites and artefacts. The so-called 'Ramayana Trail' of the Sri Lanka Tourism Development Authority is such an invention. 
But the concern for historically accurate tourism was only part of what concerned the speaker:

India's tourism authorities do not promote any alleged Ramayana sites, but sponsor a Buddhist Circuit to attract its Asian tourists. Sri Lanka sponsors of this fictional and ultimately anti-national venture started apparently under the guidance of a Tamil bureaucrat. This is similar to a few Tamil bureaucrats in 1961 which created the ideological group Pulip Padai ('Army of Tigers') which prepared for the LTTE. This Hindu fundamentalist tendency could be a not-too-subtle attempt to plant another invented homelands just as LTTE supporters and India invented a 'traditional homelands of the Tamils' prior to their war. ${ }^{4}$

Sri Lanka, it was argued, was the home to thousands of years of 'real' history - Buddhist history-and must therefore resist any attempt at annexation in the name of 'bogus' Indian? Hindu? South Asian?-history.

Sri Lanka's dense connections with the land mass across the Palk Strait have been a source of anxiety at the heart of the modern nationalist project, at least since the middle of the $20^{\text {th }}$ century. In the years immediately before and after Independence, a series of cultural movements sprung up, each in rather different ways attempting to claim an autochthonous, and therefore authentic, origin for the Sinhala Buddhist project. The Hela movement, led by Munidasa Cumaratunga, campaigned on the claim that Sinhala was not, as generally believed, an Indo-Aryan language of North Indian origin; beneath the accretions of the years, Cumaratunga believed, could be found an originary Lankan language, Hela, with no trace of alien provenance (Coperahewa 2011). At the same time, a movement called Vinaya Vardena attempted to propagate a 'pure' form of Buddhism, a Buddhism without the order of monks, and the associated institutional genealogy that connected contemporary Buddhists to the figure of the Buddha himself in what is now North India (Kemper 1978). A few years later in the early 1950s, another movement emerged, the tapasayo, self-ordained monks who again sought to short-circuit the institutional genealogies that tied regular monks to the original followers of the Buddha (Carrithers 1979).

30 All of these movements attempted to cut the ties that might bind Sri Lanka to some bigger South Asian history, and their attempts at a kind of pure, self-positing language, religion, and perhaps nation, seem to be a mirror-image response to the circumstances that impelled the Sri Lankan anthropologists of the 1950s to find themselves in a journey out into other cultural worlds.

31 In 2011 I gave a talk, loosely based on this paper, at the International Centre for Ethnic Studies in Colombo. Two years after the end of the civil war in 2009, I thought it safest to provide something comfortably academic and obscure enough in its argument to deflect criticism from the usual suspects who haunt those occasions in Colombo. I cannot say the experiment was entirely successful. In particular, my whimsical counter-factual introduction-what if things had been different and Ceylon had stayed part of the Madras Presidency in the early $19^{\text {th }}$ century-proved especially troublesome. One member of the audience was sufficiently moved to write an account in one of the country's English language newspapers. It started badly:

Ceylon, [Spencer] declared, should not have been made a 'crown colony' but 'a part of British India'.

And quickly got worse: 
[Spencer] had two faces (there are others who have adopted more masks). In the one his facial expression, tone of speech etc mimicked those of an academic; in his other self he let himself go, descending into notions of 'Empire'. It would be no surprise if he had voted for the demented Maggie Thatcher, the 'gung-ho' Blair (who waited till he was out to 'go home' to his wife's church), the also genocidal Cameron and others of their ilk. ${ }^{5}$

If nothing else, my critic's response (argued at some considerable length in the discussion that followed my presentation) demonstrated the depth of feeling behind the widespread disavowal of Lankan South Asian-ness: a talk which merely attempted to remind people of the many connections between the island and its neighbours in South and Southeast Asia, was received as a revival of Empire, and a continuation of the mission of Thatcher, Blair, and the, (somewhat unexpectedly) 'genocidal' David Cameron. I shall be more careful in the future.

All of this brings me back to my junior colleagues and the question of 'local society'. One part of their problem, of course, was that the heart of other people's anthropology was located elsewhere-in the Sinhala-dominated countryside of the interior, a part of the island that had been variously constructed as somehow realer and more Lankan since the Portuguese arrived. Place-making serves to exclude as well as include. Different parts of the island have served as the anthropological heartland at different points in the last 50 years. Most of them are rural, all of them predominantly Sinhala: the rice-growing villages of North-Central Province (Leach 1961), the Kandyan highlands (Yalman 1967; Gombrich 1971). Over 30 years ago it was claimed that at least five full ethnographic studies had been completed in an area of 9 square miles along the South coast between Tangalla and Dondra (Egan 1973: there have been more since). In contrast, the HinduMuslim patchwork of the East coast, with its inescapable reminders of the comings and goings that tie Sri Lanka to South Asia and beyond, has been relatively unexploreddespite the best efforts of exceptional researchers like McGilvray (2008), Whitaker (1999), Walker (2013), Gaasbeek (2010), Lawrence (1997) and Thangarajah (2003).

In the mid-1990s, Jayadeva Uyangoda, in a remarkable essay entitled 'Academic Texts on the Sri Lankan Ethnic Question as Biographies of a Dying Nation-state', observed that anthropology had 'made the first sustained attempt at examining Sri Lanka's contemporary manifestations of violence, practised in the service of the nation-state (1997: 8). Uyangoda's essay concluded with a section headed 'Treating the Nation-state as an Autonomous Island'. A basic problem in the academic literature, he suggests, is the isolation of Sri Lanka from the wider South Asian context, something he calls Sri Lankan exceptionalism, and that too, he argues, is symptomatic of an anachronistic clinging to the political contours of a dying political institution. We are back where I started this piece, with the critique of methodological nationalism. Let me now return to the lighthouse.

When I first encountered the Oluvil lighthouse in 2006, I took it for granted that the fanciful scheme for a new international harbour at this out-of-the-way fishing village on the East coast was long dead and buried. Then, a couple of years later, I noticed signs of construction work, and a billboard advertising a joint Sri Lankan-Danish project to build the harbour. When next I visited in 2012, the harbour was indeed constructed but there were no signs of life apart from the navy personnel guarding its entrance, and occasionally patrolling the high perimeter wall that had been built around the site. The harbour, I was told by local friends, was a disaster. Far from providing shelter, the builders had contrived to channel dangerous currents into the harbour itself. Even the 
local fishermen couldn't use it. In many ways, the harbour is typical of much post-war development across the island-a high-capital project of little immediate utility to the people who live in its shadow. As such it can serve us as a final, very concrete, metaphor, this time of the ambivalence that marks Sri Lanka's relationship to its neighbourssuperficially a gateway to the world around, which turns out to be too hazardous for anyone to use.

\section{Oluvil harbour 2012}

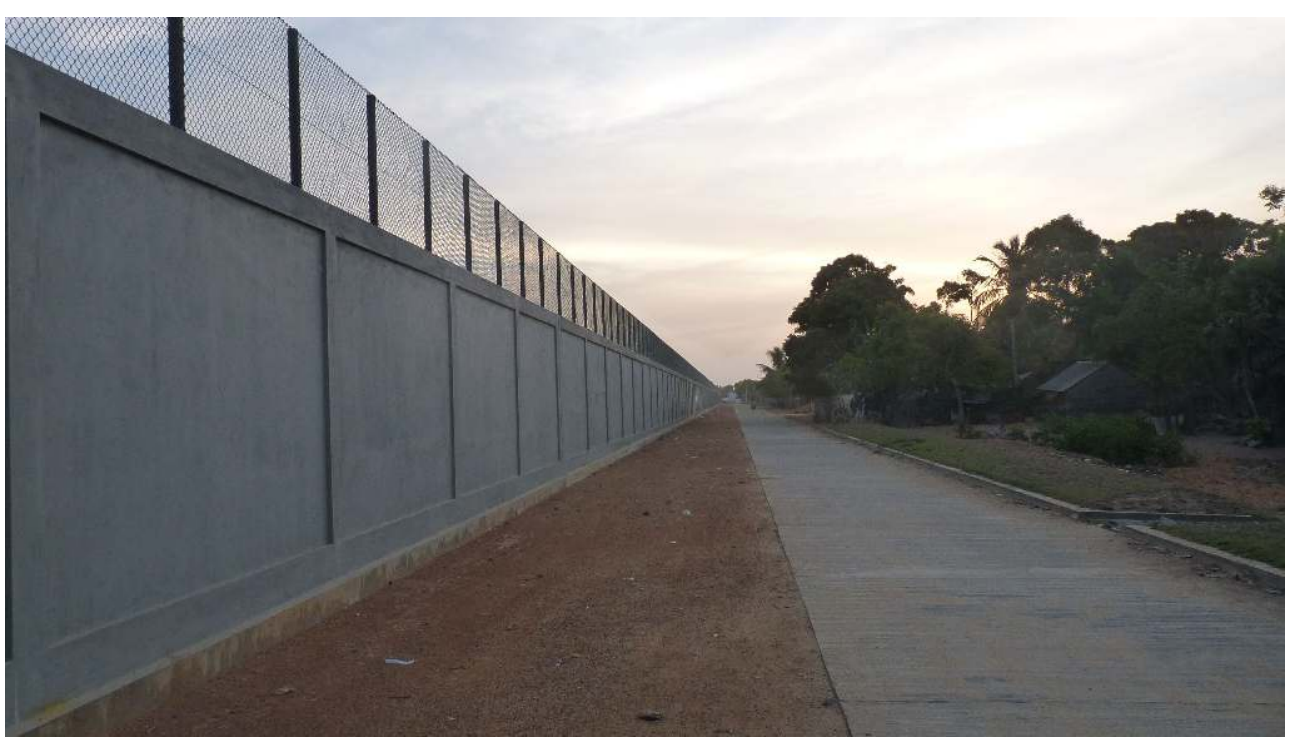

PHOTOgRAPH BY THE AUTHOR.

\section{BIBLIOGRAPHY}

Amrith, Sunil (2013) Crossing the Bay of Bengal. The Furies of Nature and the Fortunes of Migrants, Cambridge, MA: Harvard University Press.

Blackburn, Anne (2010) Locations of Buddhism: Colonialism and Modernity in Sri Lanka, Chicago: University of Chicago Press.

Carrithers, Michael (1979) 'The Modern Ascetics of Lanka and the Pattern of Change in Buddhism', Man, n.s. 14(2), pp. 294-310.

Coperahewa, Sandagomi (2011) 'Purifying the Sinhala Language: the Hela Movement of Munidasa Cumaratunga (1930s-1940s)', Modern Asian Studies, 46(4), pp. 857-91.

Daniel, Valentine (1984) Fluid Signs: Being a Person the Tamil Way, Berkeley: University of California Press.

Egan, Michael (1973) 'Introduction. 'Papers on the Ethnography of Sri Lanka”, Modern Ceylon Studies, 4(1-2), p. 1. 
Gardner, Katy; Filippo Osella (eds.) (2003) Migration, modernity and social transformation in south Asia, Special issue, Contributions to Indian Sociology, 13(1-2).

Gaasbeek, Timmo (2010) Bridging Troubled Waters: Everyday Inter-ethnic Interactiuon in a Context of Violent Conflict in Kottiyar Pattu, Trincomaless, Sri Lanka, PhD thesis, Wageningen University.

Ghosh, Amitav (1992) In an Antique Land, London: Granta.

Ghosh, Amitav (1993) 'The Slave of MS H.6', in Partha Chatterjee \& Gyan Pandey (eds.), Subaltern Studies VI: Writings on South Asian History and Society, Delhi: Oxford University Press.

Gilsenan, Michael (2003) 'Out of the Hadramaut', London Review of Books, 25(6), pp. 7-11.

Gombrich, Richard; Obeyesekere, Gananath (1988) Buddhism transformed: religious change in Sri Lanka, Princeton: Princeton University Press.

Gombrich, Richard (1971) Precept and Practice: Traditional Buddhism in the Rural Highlands of Ceylon, Oxford: Clarendon Press.

Gunawardana, Leslie (1979) 'The People of the Lion. Sinhala Consciousness in History and Historiography', Sri Lanka Journal of the Humanities, 5, pp. 1-36.

Hallisey, Charles (2003) 'Works and Persons in Sinhala Literary Culture', in Sheldon Pollock (ed.), Literary Cultures in History: Reconstructions from South Asia, Berkeley: University of California Press.

Ho, Engseng (2006) The Graves of Tarim: Genealogy and Mobility across the Indian Ocean, Berkeley: University of California Press.

Kapferer, Bruce (1983) A Celebration of Demons: Exorcism and the Aesthetics of Healing in Sri Lanka, Washington: Smithsonian Institution Press.

Kapferer, Bruce (1990) 'From the Periphery to the Centre: Ethnography and the Critique of Anthropology in Sri Lanka', in Richard Fardon (ed.), Localizing Strategies: Regional Traditions of Ethnographic Writing, Washington: Smithsonian Institution Press.

Kapferer, Bruce (1997) The Feast of the Sorcerer: Practices of Consciousness and Power, Chicago: University of Chicago Press.

Kemper, Steven (1978) ‘Buddhism without Bhikkhus: The Sri Lankan Vinaya Vardena Society', in Bardwell L. Smith (ed.) Religion and the Legitimation of Power in Sri Lanka, Chambersburg, PA: Anima.

Knox, Robert (1911) An Historical relation of Ceylon, Glasgow: MacLehose, [1681].

Lawrence, Patricia (1997) Work of Oracles, Silence of Terror: Notes on the Injury of War in Eastern Sri Lanka, PhD dissertation, University of Colorado.

Leach, Edmud (1961) Pul Eliya: A Village in Ceylon, Cambridge: Cambridge University Press.

Ludden, David (2003) Presidential Address: Maps in the mind and the Mobility of Asia, Journal of Asian Studies, 62(4), pp. 1057-78.

Malalgoda, Kitsiri (1976) Buddhism in Sinhalese Society, 1750-1900: A Study of Religious Revival and Change, Berkeley: University of California Press.

McGilvray, Dennis (2008) Crucible of conflict: Tamil and Muslim society on the east coast of Sri Lanka, Durham, NC: Duke University Press.

Obeyesekere, Gananath (1967) Land Tenure in Village Ceylon: A Sociological and Historical Study, Cambridge: Cambridge University Press. 
Obeyesekere, Gananath (1981) Medusa's hair: an essay on personal symbols and religious experience, Chicago: University of Chicago Press.

Obeyesekere, Gananath (1984) The Cult of the Goddess Pattini, Chicago: University of Chicago Press.

Pollock, Sheldon (2000) 'Cosmopolitan and Vernacular in History', Public Culture, 12(3), pp. 591-625.

Pollock, Sheldon (ed.) (2003) Literary Cultures in History: Reconstructions from South Asia, Berkeley: University of California Press. 2003.

Ricci, Ronit (2011) Islam Translated: Literature. Conversion, and the Arabic Cosmopolis of South and Southeast Asia, Chicago: University of Chicago Press.

Samaddar, Ranabir (1999) The Marginal Nation: Transborder Migration from Bangladesh to West Bengal, Delhi: Sage.

Seneviratne, H.L. (1977) Rituals of the Kandyan State, Cambridge: Cambridge University Press.

Seneviratne, H.L. (1999) The Work of Kings: The New Buddhism in Sri Lanka, Chicago, IL: University Of Chicago Press.

Sivasundaram, Sujit (2013) Islanded: Britain, Sri Lanka and the Bounds of an Indian Ocean Colony, Chicago: University of Chicago Press.

Spencer, Jonathan (1990) 'Writing Within: Anthropology, Nationalism and Culture in Sri Lanka', Current Anthropology, 31, pp. 283-300.

Spencer, Jonathan (2003) 'A nation 'living in different places': notes on the impossible work of purification in postcolonial Sri Lanka', Contributions to Indian Sociology, 37(1-2), pp. 1-23.

Spencer, Jonathan (2007) Anthropology, politics, and the state: democracy and violence in South Asia, Cambridge: Cambridge University Press.

Stirrat, Jock (2006) 'Competitive humanitarianism: relief and the tsunami in Sri Lanka', Anthropology Today, 22(5), pp. 11-6.

Subrahmanyam, Sanjay (1997) 'Connected Histories: Notes Towards a Reconfiguration of Early Modern Eurasia', Modern Asian Studies, 31(3), pp. 735-62.

Tambiah, Stanley (1986) Sri Lanka: Ethnic Fratricide and the Dismantling of Democracy, Chicago: University of Chicago Press.

Tambiah, Stanley (1992) Buddhism Betrayed: Religion, Politics, and Violence in Sri Lanka, Chicago: University of Chicago Press.

Thangarajah, Yuvi (2003) 'Ethnicization of the Devolution Debate and the Militarization of Civil Society in North-eastern Sri Lanka', in Markus Mayer, Darini Rajasingham-Senanayake \& Yuvi Thangarajah (eds.), Building Local Capacities for Peace: Rethinking Conflict and Development in Sri Lanka , Delhi: Macmillan India, pp. 15-36.

Thiranagama, Sharika (2014) 'Making Tigers from Tamils: Long-Distance Nationalism and Sri Lankan Tamils in Toronto', American Anthropologist, 116(2), pp. 265-78.

Trawick, Margaret (2007) Enemy lines: warfare, childhood, and play in Batticaloa, Berkeley: University of California Press.

Uyangoda, Jayadeva (1997) 'Academic Texts on the Sri Lankan Ethnic Question as Biographies of a Decaying Nation-State', Nethra, 1(3), pp. 7-23. 
Walker, R. (2013) Enduring Violence: Everyday Life and Conflict in Eastern Sri Lanka, Manchester: Manchester University Press.

Whitaker, Mark (1999) Amiable Incoherence: Manipulating Histories and Modernities in a Batticaloa Hindu Temple, Amsterdam: VU University Press.

Wimmer, Andreas; Glick-Schiller, Nina (2002) 'Methodological nationalism and beyond: nationstate building, migration and the social sciences', Global Networks, 2(4), pp. 301-34.

Yalman, Nur (1967) Under the Bo Tree: Studies in Caste, Kinship, and Marriage in the Interior of Ceylon, Berkeley: University of California Press.

\section{NOTES}

1. This is a revised and updated version of a paper originally written for an AAA panel on 'Theory and Area in the Anthropological Imagination: Revisiting the Anthropology of South Asia as a Place of Theory'. I am grateful to the conveners, Veena Das and Akhil Gupta, for the invitation to join the panel, and for the stimulating comments of our discussants, Arjun Appadurai and Rajeswari Sunder Rajan. Everything since is my responsibility. This paper is dedicated to the memory of Stanley Tambiah: 'Everything that was beautiful about the world, he loved' (Charles Hallisey).

2. The critique of 'methodological nationalism' should not be confused with a bien-pensant wishing away of nation-states and their continued importance in our world. It is rather a querying of the lazy identification of nation-state boundaries as self-evident boundaries for social scientific enquiry.

3. Even if it is true that 'language' and 'people' commingle with 'place', rather more than Pollock's sweeping account would allow, in early modern Sinhala assertions of the local (Gunawardana 1979).

4. S. Goonetilleke, 'Introduction: Inventing Arcaheology: The Tourist Board's 'Ramayana Trail', Royal Asiatic Society of Sri Lanka, 17 July 2010, http://www.royalasiaticsociety.lk/wp-content/ uploads/2010/07/01-Introduction.pdf, accessed 27 May, 2014.

5. G. Seneviratne, 'Jonathan Spencer and History', The Island 20 August 2011, http:// www.island.lk/index.php?page_cat=article-details\&page=article-details\&code_title=32889, accessed 27 May 2014.

\section{ABSTRACTS}

How does the idea of 'South Asia' play out in the politics and public culture of Sri Lanka? As an island, long connected by the trade routes of the Indian Ocean, it has always been a place of comings and goings. Yet, paradoxically, this fact seems to often generate efforts to imagine it as necessarily bounded and unattached to the adjacent subcontinent. The problems of place-making that follow from this move, it is suggested, may be a source of Sri Lanka's success as a producer of extraordinary anthropologists-anthropologists like the late Stanley Tambiah, whose research in Thailand was self-consciously conceived as a way of understanding the peculiar dilemmas of his homeland. 
INDEX

Keywords: Sri Lanka, island, anthropology, South Asia, connection

\section{AUTHOR}

JONATHAN SPENCER

Social Anthropology, School of Social and Political Science University of Edinburgh 